\title{
Use of the Quizizz Application in Providing Evaluation of Science Learning in Grade 6 Elementary School Students
}

\author{
Fitria D. Anggraeni ${ }^{1}$, Sukarno $^{2}$, Muzzazinah $^{3}$ \\ \{ fitriadewianggraeni82@gmail.com ${ }^{1}$, difficultyno57@gmail.com², \\ yayin_pbio@fkip.uns.ac.id $\left.{ }^{3}\right\}$ \\ Postgraduate Student Department Sebelas Maret University, Universitas Sebelas Maret, \\ Surakarta, Indonesia ${ }^{1}$ \\ Doctoral in primary teacher Education Department, Universitas Sebelas Maret, Surakarta, \\ Indonesia $^{2}$ \\ Doctoral in Biology Education Department, Universitas Sebelas Maret, Surakarta, \\ Indonesia $^{3}$
}

\begin{abstract}
Qualified human resources can be obtained through educational programs. The development of science and technology today demands a better quality of education, with the aim of producing educational products that are ready to face the challenges of the globalization era. Evaluation of learning is an important factor as a benchmark to know the expected achievement of learning goals. In achieving these learning objectives, there is a need for various support such as effective learning and evaluation media during this pandemic. Learning evaluation media during this pandemic can be done with the help of online learning evaluation media, one of which is Quizizz. Quizizz application is expected to be the right learning evaluation media, so that it can provide stimulus to increase student learning motivation. The purpose of this research is to describe the use of quizizz application in evaluating science learning in grade 6 elementary school students. The research method conducted is descriptive qualitative research that is expected to know the effect of using quizizz media through recap data of students who have changed from before using quizizz and after using quizizz. The results showed that the average student score before and after using quizizz was from an average student score of 84 to 97 . This indicates that there is an increase in student motivation marked by an increase in student grades, after using the quizizz application as an evaluation medium. Based on the results of the study, it can be concluded that quizizz media is an educational learning application media that has better effectiveness in helping the student learning process shown by the grades obtained before and after using the application.
\end{abstract}

Keywords: Evaluation Media, Motivation, Science Learning, Quizizz

\section{Introduction}

The Covid 19 pandemic began to hit China since December 2019. China was the first country to be affected by Covid 19. A novel coronavirus, SARS-CoV-2, was identified as the pathogen causing coronavirus disease (COVID-19) in Wuhan, China and has been identified as coming from a Hunan seafood market (Adnan et al., 2020) [1]. On March 11, 2020, COVID-19 
was declared a pandemic by the World Health Organization (Muniyappa \& Gubbi, 2021) [2]. Many changes have occurred in the world and in Indonesia due to the impact of the virus. This is no exception to change many orders in the world of education. The outbreak of the Covid-19 pandemic has a universal impact on Indonesia's education. Teachers, students, and education staff are all laid off. This effort was taken as a form of prevention of the spread of the Covid-19 virus which has become a global pandemic and continues to increase to dozens of positive patients in Indonesia. This alarming condition is a strong reason for the government to issue various policies so that all teaching and learning activities are carried out from home by utilizing technology tools, and taking policies to negate the National Examination and School Exams (Churiyah \& Sakdiyyah, 2020) [3].

\section{Literatur Review}

The policy not only provides an appeal but also some information devices (sites and applications) that can be accessed by schools, teachers, students and parents in facilitating and supporting teaching and learning activities while at home (Churiyah \& Sakdiyyah, 2020) [4]. Regarding learning from home, the Minister of Education and Culture emphasized that online/distance learning is carried out to provide meaningful learning experiences for students, without being burdened with demands to complete all curriculum achievements for class promotion and graduation. The Minister of Education and Culture recommends that regions that have carried out learning from home ensure that their teachers also teach from home to maintain teacher safety.

The implementation of distance learning is identical to online learning, this refers to the definition of ditance learning which is defined as teaching and learning activities carried out through the use of technology and information in a structured manner in which there is communication / relations between students and students and teachers regularly, substantively, and supportive ((Bozkurt et al., 2015) (5);(Bušelić, 2012) (6); (Grif, 2016) (7)). The implementation of distance learning underscores the absence of physical meetings between students and teachers, this can be replaced by virtual meetings in the form of video shows, presentation of text material, to graphics and images both in real time and delayed (Grif, 2016) (8).

Based on the results of interviews with teachers at SDN 1 Jarakan Tulungagung students experienced a decreased in spirit and motivation in learning during online learning. In fact, learning motivation is also a part that should not be forgotten and underestimated. The lack of motivation student to learn and the lack of student involvement in the teaching environment became fundamental problems in modern education as a result of the digital revolution (Orhan Göksün \& Gürsoy, 2019). Learning motivation is very influential on the quality and quality of learning (Afryansih, 2017).

Low motivation will affect the low enthusiasm and interest of learners in following the learning process. In addition, motivation also has a close correlation with the success learning and achievement of learners. The main factor that most affects learning outcomes is student motivation (Sigala, 2016). Students who have good motivation in their learning activities will be better able to solve problems than to withdraw from the problems faced (Kılıçoğlu, 2018) (12). Students must be motivated to be part of the learning process and be actively involved in it. Therefore, learning motivation is an important thing that should not be ruled out in all subjects. Without exception in science learning in order to achieve the expected learning 
objectives, one of which is by selecting the right learning evaluation media, so that student learning motivation is obtained to the maximally. Maximum learning motivation resulting from the learning process that takes place effectively and optimally.

Low motivation to study in school is often indicated by learning problems from these students which can hinder students from understanding the material. This indication occurs because the student's learning factor is less effective, even sometimes the students themselves are lacking in enthusiasm in following the learning in the classroom, causing the students to not understand or understand the subject matter provided. Good learning can be supported by a conducive learning atmosphere and student's relationship with the teacher can run well.

Learning motivation can be seen from the response and enthusiasm of students when participating in learning activities, with the communication of motivation students will be encouraged to learn to achieve goals and objectives, because they are confident and aware of the goodness, interests and benefits. High motivation comes to students who themselves want to achieve great success, in which case the motivation serves to trigger, elicit and direct. Students who are highly motivated students will be enterprising, persistent, unyielding, to improve their achievements. Conversely, if students who are low motivation will seem indifferent, easily discouraged, less eager in following the learning process. The problem that arises is that each student has different motivations, some are high motivation as well as low.

Based on the results of the initial interview with the teacher during the science learning process at SD Negeri 1 Jarakan, before the use of quizizz media, the teacher mentioned that there are stated some problems that occurr during the science learning process, including 1) most students are less responding to the presence of the teachers who are explaining the material, 2) when given the assignment, the students were not enthusiastic to immediately collect their assignments, 3 ) the attitude of the students when teaching and learning activities took place was not enthusiastic. This is thought to indicate that student learning motivation is not optimal. Learning motivation that is still low is thought to be one of the factors that causes student achievement to be not maximal. The problems indicate that the learning motivation of students is still lacking. This is certainly an obstacle in the process science learning in the classroom. In addition, other factors that influence this are in the digital era, such as today students are very fond of online games so that students are less able to develop themselves and lack of concentration on learning in school due to addiction to online game addiction that does not provide learning values for students.

In science learning, an appropriate evaluation media is needed that is expected to be useful for teachers and students in particular, helping students in increasing their learning motivation. Moreover, the development of science and technology at this time demands a better quality of education, in order to produce educational products that are ready to face the era of globalization. Every individual involved in education is required to play a maximum role in improving the quality of education. One of the cores of quality education lies in the learning process in the classroom, therefore teachers must have strategies in improving student learning $\mathrm{n}$ order to create a quality education that is in line with mutual expectations. The existence of learning evaluation media is one ways that teachers use to achieve success in learning activities. It can be useful to support the improvement of student learning motivation. This increase correlates with the increase in the evaluation value of students. The existence of an increase in student motivation to learn is expected to provide improvements to student achievement in school.

The use of appropriate and appropriate evaluation tools can improve student learning experiences and can make students more enthusiastic about learning. One form of learning evaluation media that can cause students to be excited about learning is learning media in the 
form of games (Agustiya et al., 2017) (13). For example, through the use of educational game applications, namely Quizizz. One of the IT-based learning evaluation media is a web tool for creating interactive quiz games that can be used as learning media. The use of online evaluation media is supported by developments in cellular technology in recent years that have allowed changes to occur, among them namely student mobile device integration or teacher to educational practice (Moqbel, 2018) (14). So quizizz is the best alternative option that is used as a learning medium available in mobile applications such as Android and app stores and can be used as a website through a browser on a computer (BAL, 2018) (15).

Quizizz is also a game-based educational app, which brings multiplayer activities to the classrooms and creates them fun in interactive and fun training clases. With Quizizz, students can practice in class on their electronic devices. Unlike other educational apps, Quizizz has game characteristics such as avatars, themes, memes and entertaining music in the learning process. Quizizz also allows students to compete with each other and motivate them to learn. Students take the quiz at the same time in class and see their live ranking on the leaderboard. Instructors can monitor the process and download the report when the quiz is over to evaluate student performance. Using this application in accounting classes helps stimulate student interest and increase student engagement (Zhao, 2019) (16).

The integration of web-based games or learning with mobile assistance is beneficial for teachers and students to make the teaching and learning process more effective (Moqbel, 2018) (17). Apart from increasing student motivation and autonomy, these technological means also facilitate students to carry out self-assessments by making use of the instant feedback and reviews offered (Wang, 2008) (18). Quizizz is also a mean of application in the form of interactive quizzes that are considered capable of attracting students' interest because because it replaces the old way of quizzes that only involve paper and pens but in the form of questions made by teachers in quizizz.com to be done by students by entering the join code. The student joins by opening the quizizz.com application app and entering the game code along with their name and can be used without the help of a projector because players see the question and answer options on their own layer. The order of the questions is randomized for each student, making it not easy for players to cheat.

Agreeing with this,quizizz is an online assessment tool as a fun multiplayer classroom activity that allows all students to practice together with their computers, Smartphones and I Pad (Yan mei et al., 2019) (19). Its use can be accessed via cell phones, so students can take advantage of technology positively and can increase student motivation in learning. In addition, the features available in quizizz can also make it easier for teachers to evaluate the learning that has been delivered and this feature also makes it easy for the assessment process to be downloaded in formal excel.

Quizizz is also an online evaluation media that can be used to conduct formative assessments. Formative assessment(Assessment for learning) is the process of collecting data on the extent of students' progress in mastering competencies, interpreting the data, and deciding effective learning activities for students in order to master the material / competence optimally. Formative assessment involves teacher and student activities that aim to monitor student learning progress during the learning process. This assessment will provide feedback for improving the learning program, knowing and reducing errors that require improvement.Formative assessment plays an important role in both traditional learning environments and e-Learning environments. Many researchers have observed that the effectiveness of student learning can be increased if the e-Learning environment includes a Web-based formative assessment design (Buchanan, 2000) (20). 
This research is supported by research conducted by Purba which is a descriptive qualitative research to find out the increase in student learning concentration through the utilization of quizizz learning evaluation in chemistry physics course I. The results of data analysis obtained from the pre-test and post-test showed an increase in student learning concentration through the use of quizizz learning evaluation in Chemistry Physics I course by 0.45 with moderate improvement interpretation. Based on in-depth interviews with students used as sampling, accuracy increased due to time constraints and students' fear of the response of answers inputted by students on quizizz. Learning evaluation using quizizz helps improve students' learning concentration (Purba, 2019) (21).

In line with this statement, research by Albeta et al. is a research on ICT-based tournaments with the quizizz application that plays a role in learning chemistry. This role is seen from the aspects of motivation and student learning outcomes. This type of research is a quasiexperimental design "The randomized pre test - post test control group design" and data analysis uses the t-test to compare the control and experimental classes. Learning that implements ICTbased tournaments with the quizizz application can increase motivation and learning outcomes. Students feel motivated to be the best. The existence of a tournament with the quizizz application makes learning fun, not boring and the concept of subject matter easier to master (Albeta et al., 2020) (22).

Based on some of the previous research using quizizz learning evaluation media, but there are some differences with this study, namely (1) in the previous research subjects were students, while this research was on elementary school students, (2) previous research media evaluation quizizz learning is used for chemistry and physics subjects, while in this research developed for science subjects Elementary School, (3) previous research used a qualitative research approach.

The description that has been stated above, researchers argue that it is important to conduct research related to the use of media in science learning in elementary school. Based on the observations have been done in Elementary School 1 Jarakan Tulungagung, if using quizizz media as a learning evaluation tool students will be more eager to learn to master the learning materials delivered by the teacher so that students can get the highest score when using quizizz media as an evaluation tool. Therefore, based on this explanation, the researcher is interested in conducting a research entitled "The Use of Quizizz Application in Providing Evaluation of Science Learning in Grade 6 Elementary School Students ".

\section{Method}

This research is a descriptive qualitative research. Qualitative research places researchers as a key instrument (researcher as key instrument), which means that qualitative researchers must collect their own data through documentation, behavioral observation, and interviews with participants. Therefore, researchers must have a broad range of theories and insights so that they can ask, analyze, and construct the objects studied more clearly.

The form of research used in this research is descriptive.This research was conducted in elementary schools in Tulungagung district, namely SDN 1 Jarakan, Tulungagung. Data collection techniques used in this study were interviews, observation and documentation. The analysis technique used in this research is an analysis technique that uses an interactive analysis model. The selection of this method is because this research is descriptive qualitative where the tipping point is deep information digging, describing and explaining, exploring and interpreting, so that the use of this model will support that goal.The interactive analysis model has four 
components: data collection, data reduction, data presentation, and inferenceand drawing conclusions.

\section{Results and Discussion}

The teacher is the main key to successful learning, as teachers that will affect students' lives. The teacher understands that each student has their own character, as well as musical instruments such as the flute, guitar, for example, have different sounds. How each character can play a role and bring success in learning. The teaching and learning process is a complex phenomenon, everything means every word, thought, action, and association and the extent to which teachers can change the environment, presentation, and teaching design, the extent to which the learning process takes place. Teachers must be able to take students into the world they will teach and give our world to students.

The learning process will run well if it using sequence or rules that have been prepared before learning is done. The teacher determine suitable learning strategies for students. All learning activities are listed in the lesson plan. After observing in grade 6 of Elementary School 1 Jarakan Tulungagung Regency, that the grade 6 teacher of Tulungagung Elementary School 1 Distance has used the lesson implementation plan and innovative learning evaluation media that is suitable for students, because learning can allow students to think critically, this is in accordance with the approach taken by the teacher is a inductive approach.

The evaluation media used by teachers in Elementary School 1 in science learning is Quizizz media. The quiz media is used by the teacher as a step to motivate students in learning. Especially in today's millennial era, children have difficulty working from using cellphones. Media Quizizz is a web tool for creating interactive games used in classroom learning. The interactive quiz created has up to 4 answer options including the correct answer and pictures can be added to the background of the question. When the quiz is over, we can share the code with students so students can enter the quiz.

Based on the results of observations, 16 students from grade 6 showed positive responses during learning using quiz media. This can also be seen from the enthusiasm shown by the students. This is supported by the teacher evaluation scores before and after using quizizz. The values are illustrated in the table below:

Table 1. Table of student evaluation scores before and after using quizizz

\begin{tabular}{cccc}
\hline No. & $\begin{array}{c}\text { Name of } \\
\text { student }\end{array}$ & Before using quizizz & After using quizizz \\
\hline 1. & Nizar & 100 & 100 \\
2. & Berly & 75 & 100 \\
3. & Dava & 100 & 100 \\
4. & Arin & 75 & 75 \\
5. & Indira & 75 & 75 \\
6. & Ikhsan & 75 & 100 \\
7. & Faza & 100 & 100 \\
8. & Akbar & 75 & 100 \\
9. & Ivory & 75 & 100 \\
10. & Rafika & 75 & 100 \\
11. & Dandi & 100 & 100
\end{tabular}




\begin{tabular}{lccc} 
12. & Safina & 75 & 100 \\
13. & Belva & 100 & 100 \\
14. & Nisa & 100 & 100 \\
15. & Habib & 75 & 100 \\
16. & Udin & 75 & 100 \\
& average & 84 & 97 \\
\hline
\end{tabular}

Based on the table, there was an increase in the average grade of students before and after using the quizizz. The previous student evaluation scores averaged 84 to 97 . It showed an increase in student grades before and after using quizizz evaluation media. Based on the data it can be know that there is an increase in student motivation which is marked by an increase in student grades, ecause after using the quizizz application students are more enthusiastic to compete and get better grades with their classmates.

The mobile learning environment changes the monotonous way of teaching in the classroom whereby the students are only listeners. In traditional education, only one way communication exists in face-to-face lectures. The teachers tend to teach unilaterally, it is important to promote interactivities among students and between the teacher and students. Traditional education is passive, lacks interaction and sometimes complicated contents are hard to be taught and understood. Poor communication between students and the teacher is one of the major problems in learning (Tabata et al., 2009) (23). However, mobile devices can aid in reducing this problem and improve interactive communication to help increase the motivation of the students (Kopf et al., 2005) (24). Many studies have examined the use of wireless mobile devices in learning. According to (Roschelle, 2003) (25), " $90 \%$ of teachers in a study of 100 palm-equipped classrooms reported that handheld was an effective instructional tools with the potential to impact student's learning positively across curricular topics and instructional activities."

Quizizz is a website that provides teachers to conduct formative assessments by giving quizzes for students of all ages. According to (26) quiz is a test of knowledge that has been obtained first, especially as a competition in the form of a game. Even though it was like a competition, the tests were entertaining. Quizzes are typically used multiple choice questions that are quick and easy to assess student answers (Tabata et al., 2009) (27) and quizzes provide questions at various levels of difficulty (28). Furthermore, students will report their answers (feedback) is given directly, automatically.

Quizizz provides multiplayer activities that allow students to practice together. The total number of players who will take the quiz is determined by the teacher. Students will be given a code to join the quiz and the teacher will make sure the students taking the quiz with the student attendance register to avoid intruders. So, not everyone can take this quiz. Quizizz supports all devices such as computers, smartphones and tablets, and quiz also has iOS, Chrome and Android apps. As a result, it can be reached in an era where technological developments are very impressive. Most students have smartphones or laptops with good internet connections that can be accessed by them to take quizzes. However, students must have their own device in other words one student, one device (Pitoyo et al., 2019). Quizizz's main features include:

(1) Student-paced: the teacher will give a time limit for each question and students need to answer before the time given for each answer is up.

(2) BYOD: quizizz can be played in various devices with a browser, including PCs, smartphones, laptops, tablets, and.

(3) Thousands of public quizzes: a great number of teacher around the globe create their own quiz and it can be shared, thus everyone can do the quiz as long as they are a member of 
quizizz. It is really helpful for the teacher to get some inspiration from another teacher in designing the quiz.

(4) Quiz Editor: quizizz allows the teachers to pluck questions from any quiz, easily add images from the internet, auto-save teachers' progress and tons of other features.

(5) Reports: this feature is the one which can give teachers detailed information about studentlevel understanding and class-level for each quiz that teachers conduct. The teacher can also download the report in the form of a spreadsheet in Microsoft Excel.

(6) Quiz Customization: Teachers can customize their quiz session in multiple options to consider the level of competition, speed, and other factors

There are also settings including question and game which teachers can use to create a quiz that they want or represent teachers' goal.

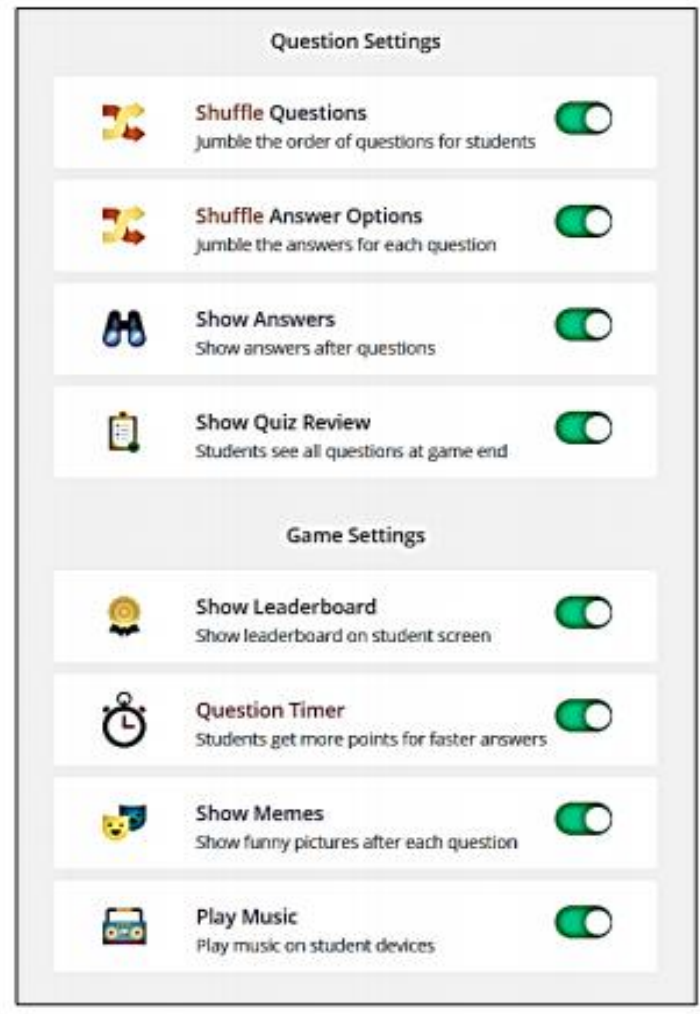

Figure 1. Questions settings of Quizizz

(Source: Pitoyo et al., 2019)

Learning evaluation media that can be created and utilized from quizizz application is interactive multimedia. This quizizz has advantages that can be used as a learning evaluation media, for example, there are data and statistics on student performance where the results can be used as material for evaluation of follow-up learning. Another feature in the form of this media is used as a medium for learning at home, namely homework (PR) which can provide opportunities for students to study outside the classroom, namely in virtual classes which are 
also a place to learn while playing with this media. Games that are creative, innovative, challenging, and fun will foster positive motivation for learners' learning desires.

Learning contents that has been prepared by designers that educators can easily find on Quizizz. This is the need for teachers to know how to make Quizizz media so that it can be used for learning for students. Learning evaluation media with Quizizz application is very easy to make by first preparing the material in the form of questions and alternative answers in this Quizizz online application. Once ready with the content, please enter the application on the web, namely www.Quizizz.com.

The way it takes to create and take advantage of this Quizizz media is to start opening the web, which is the one at that address before. For newcomers or who don't have an account, you can create a Quizizz account by registering yourself by signing up on the website, then completing the registration. If you have registered, you can use the account to log into Quizizz and then log into the web by filling in your email and password. If you have entered the web, you will be faced with a library with a collection of quiz media that has been made by the previous quiz maker. Then choose the available quizzes for students to use to study, make homework, or practice independently by selecting according to their needs.

The steps are to prepare a set of questions for the creative quiz content. Then open the application and input the questions that have been prepared. When finished, please publish it so that it can be used not only for yourself but by others as well. Thus the resulting media variations can be more widely distributed by the use of Information and Communication Technology (ICT) in learning. The use of the Quizizz application that can produce learning evaluation media can then be developed by understanding how to make it and using it in learning. Learning evaluation media generated from quizizz application can contribute to learning with expected results for improvement of learning outcomes. Now we'll take a look at the Quizizz app. Quizizz for learning various subjects and levels already exists. We can see this from the works on Quizizz.

Quizizz is a learning evaluation media in the form of online media to create a material exposure in the form of interactive quizzes enriched with animations and interactions that are very interesting and also easy to use. This application can be accessed on the site www.Quizizz.com. Figure 1. Home of Quizizz We can get Quizizz works that have become so many because they have been posted so many times on the site. However, it would be better if educators create their own creation because it can adjust to the learning needs of their students according to the learning objectives designed. If you have found the quiz set you need, you can use it by making it a live, solo or homework in our virtual classroom. This is if we take advantage of the existing ones, if not then we have to make our own quiz sets. This Quizizz application has features that have been programmed by its designers which are also designed to be easy to use by its users. Visual and audio elements are also included in this application.

The completeness of the Quizizz application is very supportive for the success of learning at various levels and subjects. The development and utilization of learning evaluation media is needed to complement things that are still incomplete at the time of making and utilizing applications because they are related to the learning needs of students. The development of instructional evaluation media that can accommodate learning at various levels and levels will be very supportive to be developed by educators and further utilized by students in increasing their competence.

As previously mentioned, the Quizizz application is an online application service that can be developed into a learning evaluation media that is rich in advantages that can be used in learning various subjects and levels. Furthermore, the learning evaluation media produced from the Quizizz application is how to use it in order to meet the needs of learning evaluation media starting from the elementary school level. 
There are still many educators who teach the various maples and levels of Quizizz who do not understand both their manufacture and use. This existing condition should change with an increase in the understanding and skills of educators to create and use Quizizz as a learning evaluation medium so that educators can improve their insights, knowledge, and skills in making Quizizz-based media as a learning evaluation media in this digital era. Educators are expected to be more creative in their work and also select existing learning evaluation media and follow up with the use of media.

\section{Conclusion}

The Covid-19 pandemic has had an impact and demanded changes in a limited time including the impact on educational aspects in the form of changes in distance online learning models that tend to be less effective in increasing students' interest and motivation for learning. This explains that it needs effective media in evaluating and learning students in order to achieve the expected goals, the application is quizizz. The results of the research that has been done in grade 6 students at SDN 1 Jarakan Tulungagung in the form of literature studies and interviews with student teachers obtained data that the learning using the appropriate learning plan and evaluation media and supported by quizizz application received a positive response. Based on the document of student value recap from the teacher shows that there is an increase in the average value of students before and after using quizizz. The previous student evaluation score averaged 84 and after using quizizz to 97 . The data showed that there was an increase in student motivation marked by increased grades, and a good response in the form of a high spirit of learning through application-based supporting media.With the development of educational technology becomes an important role that can be used to build quality human resources and have good digital literacy. This will have an impact on the readiness of distance learning systems in all situations.

\section{References}

[1] Adnan, M., Khan, S., Kazmi, A., Bashir, N., \& Siddique, R. (2020). COVID-19 infection : Origin , transmission , and characteristics of human coronaviruses. Journal of Advanced Research, 24, 91 98. https://doi.org/10.1016/j.jare.2020.03.005

[2] Muniyappa, R., \& Gubbi, S. (2021). COVID-19 pandemic, coronaviruses, and diabetes mellitus. 736-741. https://doi.org/10.1152/ajpendo.00124.2020

[3] Churiyah, M., \& Sakdiyyah, D. A. (2020). International Journal of Multicultural and Multireligious Understanding Indonesia Education Readiness Conducting Distance Learning in Covid-19 Pandemic Situation. 491-507.

[4] Churiyah, M., \& Sakdiyyah, D. A. (2020). International Journal of Multicultural and Multireligious Understanding Indonesia Education Readiness Conducting Distance Learning in Covid-19 Pandemic Situation. 491-507.

[5] Bozkurt, A., Akgun-ozbek, E., Yilmazel, S., Erdogdu, E., Ucar, H., Guler, E., \& Sezgin, S. (2015). Trends in Distance Education Research : A Content Analysis of Journals 2009-2013. 16(1), 330363.

[6] Bušelić, M. (2012). Distance Learning - concepts and contributions. 23-34. 
[7] Grif, B. (2016). A Faculty's Approach to Distance Learning Standardization. 11, 157-162. https://doi.org/10.1016/j.teln.2016.04.004

[8] Grif, B. (2016). A Faculty's Approach to Distance Learning Standardization. 11, 157-162. https://doi.org/10.1016/j.teln.2016.04.004

[9] Orhan Göksün, D., \& Gürsoy, G. (2019). Comparing success and engagement in gamified learning experiences via Kahoot and Quizizz. Computers and Education, 135(February), 15-29. https://doi.org/10.1016/j.compedu.2019.02.015

[10] Afryansih, N. (2017). Hubungan Motivasi Belajar Dengan Hasil Belajar Siswa Geografi Sman 5 Padang. Jurnal Spasial, 3(1). https://doi.org/10.22202/js.v3i1.1600

[11] Sigala, L. (2016). Hubungan Persepsi Siswa Tentang Cara Mengajar Guru Dengan Motivasi Belajar Siswa yang Pernah Mengikuti Remedial. 4(3), 310-315.

[12] K1lıçoğlu, G. (2018). Study on the relationship between social studies course self-efficacy and motivation levels of secondary school students. Universal Journal of Educational Research, 6(8), 1743-1748. https://doi.org/10.13189/ujer.2018.060816

[13] Agustiya, F., Sunarso, A., Haryani, S., Negeri, S. D., Karanganyar, K., Demak, K., \& Tengah, J. (2017). Influence of CTL Model by Using Monopoly Game Media to The Students' Motivation and Science Learning Outcomes. Journal of Primary Education, 6(2), 114-119.

[14] Moqbel, M. S. S. (2018). Self-assessment in EFL Grammar Classroom: A Study of EFL Learners at the Centre for Languages and Translation, Ibb University. International Journal for Research in Education, 42(2), 289-324.

[15] BAL, S. (2018). International Journal of Language Academy Using Quizizz . Com To Enhance PreIntermediate Students ' Vocabulary Knowledge Orta Düzey Öğrencilerin Kelime Bilgisi ni Arttırmak İçin. International Journal of Language Academy, 6(September), 295-303.

[16] Zhao, F. (2019). Using quizizz to integrate fun multiplayer activity in the accounting classroom. International Journal of Higher Education, 8(1), 37-43. https://doi.org/10.5430/ijhe.v8n1p37

[17] Moqbel, M. S. S. (2018). Self-assessment in EFL Grammar Classroom: A Study of EFL Learners at the Centre for Languages and Translation, Ibb University. International Journal for Research in Education, 42(2), 289-324.

[18] Wang, T. H. (2008). Web-based quiz-game-like formative assessment: Development and evaluation. Computers and Education, 51(3), 1247-1263. https://doi.org/10.1016/j.compedu.2007.11.011

[19] Yan mei, S., Yan Ju, S., \& Adam, Z. (2019). Implementing Quizizz as Game Based Learning in the Arabic Classroom. European Journal of Social Science Education and Research, 5(1), 194-198. https://doi.org/10.2478/ejser-2018-0022

[20] Buchanan, T. (2000). The efficacy of a World-Wide Web mediated formative assessment. Journal of Computer Assisted Learning, 16(3), 193-200. https://doi.org/10.1046/j.1365-2729.2000.00132.x

[21] Purba, L. S. L. (2019). Peningkatan Konsentrasi Belajar Mahasiswa Melalui Pemanfaatan Evaluasi Pembelajaran Quizizz Pada Mata Kuliah Kimia Fisika I. Jurnal Dinamika Pendidikan, 12(1), 29. https://doi.org/10.33541/jdp.v12i1.1028

[22] Albeta, S. W., Nofianti, N., \& Rahmandani, S. (2020). Peranan Turnamen Berbasis Ict Dengan Aplikasi Quizizz Terhadap Pembelajaran Kimia. Jurnal Pendidikan Kimia Universitas Riau, 5(1), 11. https://doi.org/10.33578/jpk-unri.v5i1.7778

[23] Tabata, Y., Yin, C., Ogata, H., \& Yano, Y. (2009). Mobile phone-based quiz system for learning foreign culture. Proceedings of the 17th International Conference on Computers in Education, ICCE 2009, June 2014, 603-607.

[24] Kopf, S., Scheele, N., Winschel, L., \& Effelsberg, W. (2005). Improving Activity and Motivation of Students with Innovative Teaching and Learning Technologies. April.

[25] Roschelle, J. (2003). wireless mobile devices. 19(May), 260-272. 
[26] Tabata, Y., Yin, C., Ogata, H., \& Yano, Y. (2009). Mobile phone-based quiz system for learning foreign culture. Proceedings of the 17th International Conference on Computers in Education, ICCE 2009, June 2014, 603-607.

[27] Pitoyo, M. D., Sumardi, A., \& Asib, A. (2019). Gamification based assessment: A Test Anxiety Reduction through Game Elements in Quizizz Platform. International Online Journal of Education and Teaching (IOJET), 6(3), 456-471. http://iojet.org/index.php/IOJET/article/view/626 